\title{
Replacing Development: An Afro-Communal Approach to Global Justice
}

\section{Thaddeus Metz}

To cite this article: Thaddeus Metz (2017) Replacing Development: An Afro-Communal Approach to Global Justice, Philosophical Papers, 46:1, 111-137

To link to this article: http://dx.doi.org/10.1080/05568641.2017.1295627
(2) 2017 The Author(s). Published by Informa UK Limited, trading as Taylor \& Francis Group
Published online: 21 Mar 2017.

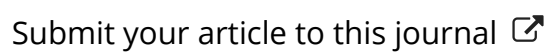

Q View related articles ๘

View Crossmark data $\nearrow$ 


\title{
Replacing Development: An Afro-Communal Approach to Global Justice Thaddeus Metz
}

\begin{abstract}
In this article, I consider whether there are values intrinsic to development theory and practice that are dubious in light of a characteristically African ethic. In particular, I focus on what a certain philosophical interpretation of the sub-Saharan value of communion entails for appraising development, drawing two major conclusions. One is that a majority of the criticisms that have been made of development by those sympathetic to African values are weak; I argue that, given the value of communion, development should not be rejected because it is essentially, say, overly materialistic and scientistic, or insufficiently spiritual and local. The second conclusion, however, is that three criticisms of development are strong from the perspective of Afro-communalism and are particularly powerful when set in that context. I argue that development theory and practice are characteristically anthropocentric, individualist and technocratic, and that a reading of the sub-Saharan value of communion provides a unitary foundation for rejecting these features and for grounding an alternative, more relational approach to social progress and to what justice demands from the West in relation to Africa.
\end{abstract}

\section{Introduction}

There are three salient conceptions of progress in the modern Western tradition that intellectuals and policy makers have often invoked to appraise the standing of Euro-America-Australasia and rest of the world in relation to it, namely, meta-narrative, economic growth and development. Although the latter one grew out of the former two, I focus strictly on it here, enquiring into development's plausibility as an account of what sub-Saharan societies ought to be doing and of how Western ones should be helping them.

Those sympathetic to Africa have often criticized development for serving nefarious functions, particularly for legitimating Western

This is an Open Access article distributed under the terms of the Creative Commons Attribution-NonCommercial-NoDerivatives License (http://creativecommons.org/licenses/by-nc-nd/4.0/), which permits non-commercial re-use, distribution, and reproduction in any medium, provided the original work is properly cited, and is not altered, transformed, or built upon in any way. 
domination of Africa $^{1}$ and for expressing an attitude of superiority on the part of the West. ${ }^{2}$ Sometimes critics have also contended that development has failed on its own terms to alleviate poverty in Africa. ${ }^{3}$ I believe that while these criticisms are plausibly true of development in practice, they do not target the heart of development theory. In principle, there could be a form of development that would neither serve to facilitate Western domination of Africa, nor express Western arrogance over it, nor fail to reach its own ends. Just imagine, for example, that African governments successfully undertook development on their own. Would there still be a moral problem with this sort of development? ${ }^{4}$

In this article I defend an affirmative answer to this question. I argue that there are value judgments central to both development theory and practice that are dubious in light of a characteristically African ethic. More specifically, I focus on what a certain philosophical interpretation of the sub-Saharan value of communion entails for appraising development, drawing two major conclusions. One is that a majority of

\footnotetext{
1 E.g., Arturo Escobar, 'Imagining a Post-Development Era?', Social Text 31/32 (1992): 2056; Majid Rahnema, 'Towards Post-Development', in Majid Rahnema and Victoria Bawtree (eds), The Post-Development Reader (London: Zed Books, 1997), 377-403; and Eiman ZeinElabdin, 'Postcoloniality and Development: Development as a Colonial Discourse', in Lansana Keita (ed.), Philosophy and African Development Theory and Practice (Dakar: CODESRIA, 2011), 215-230.

2 For just one clear statement, see Aram Ziai, 'Development Discourse and Its Critics', in Aram Ziai (ed.), Exploring Post-development (New York: Routledge, 2007), 3-17 at 8.

3 For instance, Rahnema, 'Towards Post-Development', 378-379, 391; James Ferguson, 'Development and Bureaucratic Power in Lesotho', in Majid Rahnema and Victoria Bawtree (eds), The Post-Development Reader (London: Zed Books, 1997), 223-233; Sally Matthews, 'Post-development Theory and the Question of Alternatives: A View from Africa', Third World Quarterly 25 (2004): 373-384; Kwesi Kwaa Prah, 'Culture: The Missing Link in Development Planning in Africa', in Lansana Keita (ed.), Philosophy and African Development Theory and Practice (Dakar: CODESRIA, 2011), 155-168; and Ewelina Róża Lubieniecka, 'Does Post-development Theory Find Alternatives to Westernization of International Relations? African Perspective', paper presented at the $8^{\text {th }}$ Pan-European Conference on International Relations (2013).

4 Setting aside Claude Ake's point that development-talk has also served to legitimate the domination of African elites over their people in his Democracy and Development in Africa (Washington, DC: The Brookings Institution, 1996).
} 
the criticisms that have been made of development by those sympathetic to African values are weak; I argue that, given the value of communion, development should not be rejected because it is essentially, say, overly materialistic and scientistic, or insufficiently spiritual and local.

The second conclusion, however, is that three criticisms of development are strong from the perspective of Afro-communalism and are particularly powerful when set in that context. I argue that development theory and practice are anthropocentric, individualist and technocratic, and that a reading of the sub-Saharan value of communion provides a unitary foundation for rejecting these features and for grounding an alternative, more relational approach to social progress and to what justice demands from the West in relation to Africa.

Note that my main aim is to apply a certain Afro-communal value to the concept of development. I lack the space to defend this value systematically as a ground of public morality, ${ }^{5}$ and must rest content with merely providing a prima facie motivation for that. In addition, although I do offer reasons to think that the concept of communion has a sub-Saharan pedigree, I cannot here provide a thorough reckoning of why I believe the 'African' label for it is apt, particularly in the face of some similarities with values of other indigenous peoples. ${ }^{6}$

In the following, I begin by explaining what I mean by 'development', clarifying what it is that I am evaluating in this article (Section 2), after which I advance the Afro-communal value that I use to do so (Section 3). Then, taking communion for granted, I invoke it to demonstrate that others who have accepted characteristically sub-Saharan values (or the

5 Which I have sought to do in, for instance, Thaddeus Metz, 'Ubuntu as a Moral Theory and Human Rights in South Africa', African Human Rights Law Journal 11 (2011): 532-559, 'Developing African Political Philosophy: Moral-Theoretic Strategies', Philosophia Africana 14 (2012): 61-83, and 'The Western Ethic of Care or an Afro-Communitarian Ethic?: Specifying the Right Relational Morality', Journal of Global Ethics 9 (2013): 77-92.

6 On which see, e.g., George Silberbauer, 'Ethics in Small-Scale Societies', in Peter Singer (ed.), A Companion to Ethics (Oxford: Blackwell, 1991), 14-28. For an account of how I believe geographical labels such as 'African' are plausibly used, see Thaddeus Metz, 'How the West Was One: The Western as Individualist, the African as Communitarian', Educational Philosophy and Theory 47 (2015): 1175-1184. 
values of indigenous peoples more broadly) have sometimes criticized development for several reasons that are weak (Section 4). Next, I show that communion entails that three of the criticisms, however, are strong, that it provides a unitary foundation for the most telling objections to development (Section 5). I conclude by briefly considering some implications of rejecting development-talk and creating a new vocabulary for just social change (Section 6).

\section{What Is Development?}

In seeking to answer this question, I am not trying to articulate a set of necessary and sufficient conditions for the concept of development (though I will not complain if I have by chance done so). I will be content to have instead spelled out features characteristic of development theory and practice.

For much of the post-independence era in Africa, development had been premised on the aim of indefinite economic growth, ${ }^{7}$ which was powerfully criticized for three major reasons, namely, for being inconsistent with ecological concerns, insufficiently related to people's quality of life, and unconcerned with the distribution of wealth, viz., towards the worst-off. However, these days standard development theory and practice require environmental sustainability, expected improvement in people's welfare (often cashed out in terms of needs or capabilities), and a concern for who receives the benefits. Any plausible account of the nature of development should not be overly narrow for placing economic growth at its centre; the latter should be understood to be merely one, unattractive form that the former once took.

Conversely, it would be a mistake to construe the concept of development too broadly, relative to my aim in this article, which is to target a certain Western conception of social progress. So, it will not do to think of development as merely 'purposive (teleological) growth' where

7 Although this is well known, one might see the trenchant analysis in Cornelius Castoriadis, "Reflections on "Rationality" and "Development", repr. in Thesis Eleven 10/11 (1984/85): 18-36. 
'the goal of development is greater human, material, technological and cultural welfare'. ${ }^{8}$ This analysis of the concept of development does not uniquely pick out the particular sorts of practices that have been undertaken in Africa and recommended for it over the past 60 years or so.

To make headway, consider some representative examples of the way that the word 'development' has been used recently in respect of subSaharan Africa. Quintessential instances include the World Bank, the United Nations or a Western government enabling farmers to participate on the global market by reducing tariffs or enabling them to access seeds, offering training in macroeconomic planning and fiscal management to government employees, deploying new technologies, such as cell phone applications, to enable people to participate in the banking system, educating the police about human rights and gender issues, helping primary school teachers develop modules that will foster literacy and numeracy, and providing electronic stock management systems to medical clinics. ${ }^{9}$ Although development has often had a nonAfrican agent driving it, that is not a necessary condition, as there have of course been times when African states themselves, as well as parastatals and NGOs based in them, have done so, though typically in 'partnership' with a better resourced external body.

Using these examples as a springboard, I suggest that the following captures much of what is central to development, construed as a Western conception of progress that has often been applied to Africa and taken on board by African institutions: the quest to improve non-Western people's standard of living and to protect their human rights, as exemplified by the West, principally through changes to state policy and corporate practice that are scientifically informed and typically involve sophisticated technology, improved efficiency and the adoption of impersonal norms.

8 Godfrey Tangwa, 'Philosophy, Democracy and Development', in Lansana Keita (ed.), Philosophy and African Development Theory and Practice (Dakar: CODESRIA, 2011), 177-195 at $177,178$.

9 These examples were largely taken from the website listing the International Development Projects run by the Canadian government, http://www.international.gc.ca/developmentdeveloppement/aidtransparency-transparenceaide/browser-banque.aspx?lang=eng. 
One implication of this analysis is that the Western world by definition cannot develop. That might in fact be welcome, since the discourse invariably distinguishes between 'developed' and 'undeveloped' or (more politically correct) 'developing' countries. However, if the reader believes that development could take place in Europe, North America and Australasia, then one could either remove mention of 'non-Western' people as the intended beneficiaries and speak merely of 'people' in general, or speak of 'mainly' non-Western people as the ones meant to benefit. The crucial point is that the non-Western parts of the world are supposed to 'catch up' to the Western part.

I leave further refinements of this characterization of development to other philosophers. I submit that it has the merits of avoiding being either too narrow or too broad, successfully picking out a Western approach to social progress that has been salient since the independence of sub-Saharan countries from colonial powers. The next issue to address is why one might reasonably find it objectionable. Would it not be ideal for these countries to come closer to the milk and honey conditions of the West? What in the world is wrong with projects of the sort adumbrated above?

\section{A Philosophical Interpretation of the African Value of Communion}

Although some philosophical articulations of sub-Saharan values take lifeforce $^{10}$ or the common good ${ }^{11}$ as basic, or appeal to invisible agents such as ancestors and the not-yet-born, ${ }^{12}$ I have argued elsewhere that a secular and relational conception of them is particularly attractive, at least for a

10 E.g., Noah Dzobo, 'Values in a Changing Society: Man, Ancestors, and God', in Kwasi Wiredu and Kwame Gyekye (eds), Person and Community (Washington, DC: Council for Research in Values and Philosophy, 1992), 223-240; and Laurenti Magesa, African Religion: The Moral Traditions of Abundant Life (Maryknoll, NY: Orbis Books, 1997).

11 Most prominently Kwame Gyekye, Tradition and Modernity: Philosophical Reflections on the African Experience (New York: Oxford University Press, 1997).

12 E.g., Bénézet Bujo, 'Differentiations in African Ethics', in William Schweiker (ed.), The Blackwell Companion to Religious Ethics (Malden, MA: Blackwell, 2005), 423-437; and Munyaradzi Felix Murove, 'The Shona Ethic of Ukama with Reference to the Immortality of Values', The Mankind Quarterly 48 (2007): 179-189. 
global audience of philosophers, policy-makers and activists. ${ }^{13}$ Roughly, from this perspective, communal relationships with human persons and certain animals are what merit pursuit for their own sake. In this section, I expound this ethic, applying it only in the following sections.

My favoured philosophical rendition of African values is grounded on relational ideas such as these, advanced by a variety of sub-Saharan thinkers:

Every member is expected to consider him/herself an integral part of the whole and to play an appropriate role towards achieving the good of all. ${ }^{14}$

Harmony is (to be) achieved through close and sympathetic social relations within the group. ${ }^{15}$

The fundamental meaning of community is the sharing of an overall way of life, inspired by the notion of the common good. ${ }^{16}$

(T)he purpose of our life is community-service and communitybelongingness. ${ }^{17}$

If you asked ubuntu (the Nguni word for personhood or virtue-ed.) advocates and philosophers: What principles inform and organise your life? ... the answers would express commitment to the good of the community in which their identities were formed, and a need to experience their lives as bound up in that of their community. ${ }^{18}$

These quotations are of interest for two reasons. One is that they suggest that a certain kind of relationship is to be pursued as an end, not merely as a means. ${ }^{19}$ Another is that they specify the nature of this relationship,

13 For some key papers, see note 5 above.

14 Segun Gbadegesin, African Philosophy (New York: Peter Lang, 1991), 65.

15 Yvonne Mokgoro, 'Ubuntu and the Law in South Africa', Potchefstroom Electronic Law Journal 1 (1998): 15-26 at 17.

16 Kwame Gyekye, Beyond Cultures; Ghanaian Philosophical Studies, Volume III (Washington, DC: Council for Research in Values and Philosophy, 2004), 16.

17 Pantaleon Iroegbu, 'Beginning, Purpose and End of Life', in Pantaleon Iroegbu and Anthony Echekwube (eds), Kpim of Morality Ethics (Ibadan: Heinemann Educational Books, 2005), 440-445 at 442 .

18 Gessler Muxe Nkondo, 'Ubuntu as a Public Policy in South Africa', International Journal of African Renaissance Studies 2 (2007): 88-100 at 91.

19 I acknowledge that Gyekye is committed to denying this, given that he believes the common good is foundational. 
in terms of two logically distinct facets. ${ }^{20}$ On the one hand, there is what I call 'identifying with' others, that is, considering oneself part of the whole, being close, sharing a way of life, belonging and being bound up with others, and, on the other, there is 'exhibiting solidarity' with them, i.e., achieving the good of all, being sympathetic, advancing the common good, servicing and being committed to others' good.

I call the combination of identity and solidarity 'communion' (or sometimes 'harmony'). I abjure the word 'community', in part because it is used in a variety of ways and in part because it might suggest the (Western) communitarian view that appropriate norms are determined by a group's attitudes or culture. In contrast, communion is meant to be an objective standard by which to determine whether a group's norms are appropriate, whether it has moral reason to change its attitudes or culture.

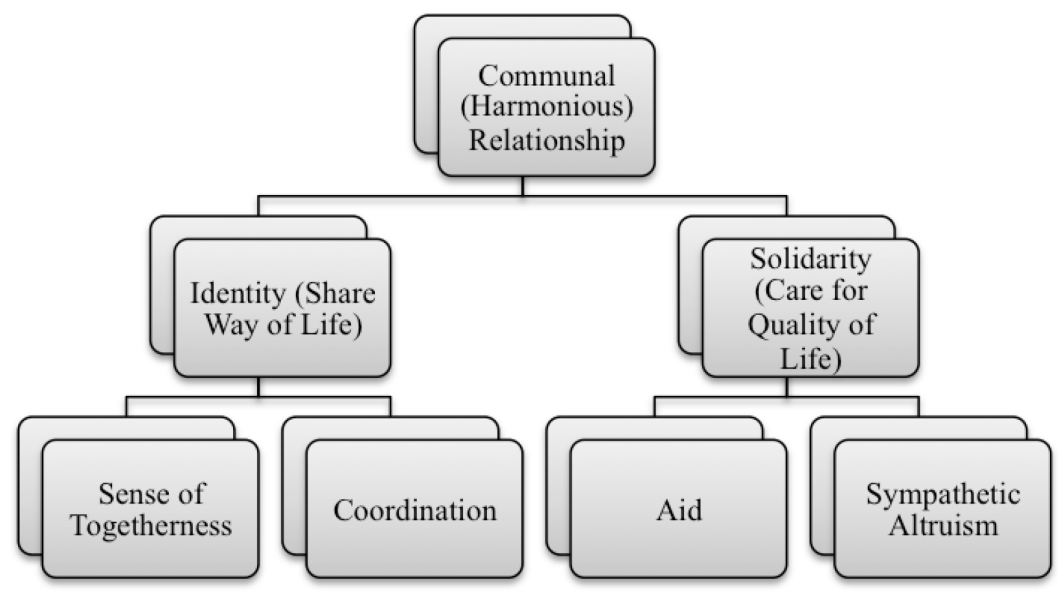

Figure 1: Schematic Representation of Communion

20 Which I first distinguished and reconstructed in Thaddeus Metz, 'Toward an African Moral Theory', Journal of Political Philosophy 15 (2007): 321-341; for a somewhat revised version, see Isaac Ukpokolo (ed.), Themes, Issues and Problems in African Philosophy (London: Palgrave Macmillan, 2017), 97-119. 
Supposing that communal relationship, as above, merits pursuit for its own sake in some way, the question arises as to which beings merit it. Roughly, with whom or what should one commune? ${ }^{21}$ By my philosophical reconstruction, beings have a full moral status (a dignity) if they are capable of being both subjects and objects of communion, that is, if they can exhibit identity and solidarity with another and another can exhibit identity and solidarity with them. Normal human persons fit this description. There is some moral reason to commune with such beings, if they have not misused their capacity to commune or if relating discordantly to them (roughly, with subordination and harm) is not necessary to rebut their wrongdoing.

Other kinds of beings have a partial moral status, insofar they are capable of being merely the object of communion, that is, if they cannot exhibit identity and solidarity with us but we can exhibit identity and solidarity with them. Animals 'higher' than insects, arachnids and the like can be objects of communion with us. When it comes to birds, mice, cats, dogs, giraffes, lions, elephants and apes, we can enjoy a sense of togetherness with them, foster their ends, do what is likely to make their lives go well, and do so out of sympathy and for their own sake. There is some moral reason to commune with such beings, although less reason than with those beings that have a dignity.

The further question of precisely how to respond to the value of communion is complicated, and is one I do not need to explore in detail here in order to appraise development. In a nutshell, I reject a consequentialist prescription to maximize communal relationships, and instead advocate a deontological principle according to which one should respect beings insofar as they are capable of communion. Such respect will mean, in part, communing with them and helping them to commune, but it will not mean, say, acting discordantly towards innocents even if doing so would promote communion in the long run.

21 For a systematic articulation and defence of the following answer, see Thaddeus Metz, 'An African Theory of Moral Status: A Relational Alternative to Individualism and Holism', Ethical Theory and Moral Practice 15 (2012): 387-402. 
In other work I have argued that this philosophical interpretation of the sub-Saharan value of communion easily entails and plausibly explains a variety of salient practices amongst indigenous sub-Saharan peoples, ones that have some intuitive moral pull even for those outside this tradition. For example, it naturally accounts for their: recurrent search for consensus in decision-making; inclination towards reconciliation when responding to wrongdoing; tendency to hold land in common and to avoid great inequalities of wealth; and disposition to accord animals a partial moral standing, one lower than humans but greater than plants. ${ }^{22}$

I lack the space to discuss further the African credentials of this principle, and must focus on its prima facie plausibility as a normative ground of public policy. Whereas the utilitarian believes that institutions ought to serve the function of enhancing subjective well-being, the Kantian believes they should protect and enhance people's autonomy, and the capabilities theorist believes they should ensure that people have the ability to function in objectively valuable ways, the adherent to communion contends (roughly) that institutions ought to commune and enable others to do so. The latter approach entails that conditions such as these are to be prized: a state that cares for the quality of life of its residents; a business that is willing to forgo some profits so as to strengthen ties with stakeholders; a populace that is cohesive in the sense of enjoying a national identity and being disposed to cooperate across ethnic lines; and a household in which marriages are evenhanded and stable and in which children are reared with wisdom. From this Afrocommunal perspective, roughly speaking, 'immorality is the word or deed which undermines fellowship', ${ }^{23}$ i.e., wrongness is more or less discordant behaviour that treats innocent parties as separate and inferior, subordinates them, is expected to harm them, and is done consequent to indifference or cruelty. This ethic, too, merits consideration when thinking about how to organize a society.

22 See, e.g., 'Toward an African Moral Theory', 'Developing African Political Philosophy' and 'An African Theory of Moral Status'.

23 Peter Kasenene, Religious Ethics in Africa (Kampala: Fountain Publishers, 1998), 21. 


\section{Weak Criticisms of Development}

In the rest of this article, I take for granted the prescription to treat others with respect insofar as they are capable of being party to communal relationships. Supposing that communion is key, it follows that several of the major criticisms that have been made of development in the literature lack force. This is true even for those critics who would describe themselves as 'Africanists'. From my perspective, they have not honed in on respects in which development truly undermines fellowship.

\subsection{Too Little Spirituality?}

Some adherents to characteristically African values have criticized the neglect by development theory and practice of 'spiritual' considerations, such as the inclination to see invisible agents, say, ancestors or God, in the world. As one African scholar has put it, '(T)he alliance of progress, science and technology leads to social and spiritual bankruptcy. Having objectified nature and people, God too becomes impersonal'. ${ }^{24}$

It is true that a concern to foster cell-phone banking, improve supply chain management and facilitate trade on the world market means a neglect of what traditional sub-Saharans might consider holy. However, I do not believe that this necessarily indicates a moral shortcoming with development. A strict focus on the perceptible (or what Westerners would call the 'physical') need not involve any failure to commune, as construed in the previous section.

There can sometimes be secular reasons for a concept of social progress to include imperceptible ('spiritual') elements. ${ }^{25}$ For example, if

24 Harvey Sindima, 'Community of Life', The Ecumenical Review 41 (1989): 537-551 at 542. See also Ratan Basu, 'Why the Human Development Index Does Not Measure Up to Ancient Indian Standards', Cultural Mandala 6 (2005), http://www.internationalrelations.com/CM6-2WB/HDI-Ancient-India.htm; and Aram Ziai, 'Post-Development Concepts? Buen Vivir, Ubuntu and Degrowth', paper presented at the Degrowth Conference in Leipzig (2014), 2, http://www.degrowth.de/en/catalogue-entry/post-developmentconcepts-buen-vivir-ubuntu-and-degrowth/.

25 For considerations beyond those mentioned here see Thaddeus Metz, 'Gross National Happiness: A Philosophical Appraisal', Ethics and Social Welfare 8 (2014): 218-232 at 223225. 
many people have exhibited identity and solidarity in a religious way over a long span of time, then considerations of communion entail that there is some moral reason not to undermine that practice (at least if it does not involve severe discord towards innocent parties). Development may indeed be faulted for running roughshod over this facet of people's lives, but the ground of the criticism is that it disregards communion, not that it neglects God.

\subsection{Too Much Science?}

Although some of the post-development literature, particularly with an African flavour, is critical of science for eclipsing 'spiritual' ways of interpreting the world, as per the previous objection, there is the further, distinct objection that science is simply unlikely to work in a subSaharan context. Consider this claim:

Attempts to achieve high productivity are often counter-productive. And usually, it is those already struggling to make ends meet who pay the price for national gambles. Science has much to answer for in Africa in this respect. Africans were encouraged to use fertilizers. Many of these fertilizers were not tested for the particular soils in which they were being used. The result was that wrong types of fertilizers were used. Consequently, soils got burnt with the wrong salts applied to them. ${ }^{26}$

However, this sounds like the problem is bad science or not enough science, rather than too much science simpliciter. A good scientist would have considered whether a fertilizer that works in one kind of soil would be likely to work in another of a different chemical composition. In addition, a sensible policy maker would have run a pilot study to test the fertilizer in one, circumscribed area, before encouraging its widespread adoption.

More deeply, insofar as a communal relationship includes aid, it prescribes doing what is likely to make people's lives go better, which includes meeting their biological, psychological and social needs. The scientific method has been humanity's most successful means by which to

26 Sindima, 'Community of Life', 550. 
understand the nature of reality, and should not be neglected when seeking to improve people's quality of life. Surely, it would be wrong to fund any aid project intending to free up human resources in Africa by deploying zombies in the army, ${ }^{27}$ or to disseminate a concoction meant to cure HIV/AIDS that was sent by a purported spirit to a truck driver in a dream, ${ }^{28}$ or to harness electricity discharged by flying witches to power African economies. ${ }^{29}$ These projects would be unjust for a government to support because doing so would flout the communal value of solidarity, i.e., would constitute an utter failure to do what, for all we can tell with reliable epistemic means, is likely to enable people to live well.

\subsection{Too Much Materialism?}

More than a few in the field suggest that standard development theory is too materialistic for addressing solely or mainly financial, technological and consumerist interests. For instance, one finds the criticism that 'development is about paving the way for the achievement of those conditions that characterize rich societies: industrialization, agricultural modernization, and urbanization' ${ }^{30}$ or that the key problem with development theory is that it is focused on 'material affluence' and 'commodities'. ${ }^{31}$

However, I do not believe that this objection is fair. An awful lot of contemporary development has involved seeking to improve health, education and human rights, which are not essentially industrial or economic. This is true not merely in theory, but also in practice. Idiosyncratic are neither Amartya Sen's and Martha Nussbaum's

27 Suggested by Credo Mutwa, Indaba, My Children (Repr. Edinburgh: Payback Press, 1998), 657.

28 Discussed in (but not endorsed by) Kerry Cullinan, 'Health Officials Promote Untested uBhejane'. Health-E News 22 March 2006, https:/www.health-e.org.za/2006/03/22/healthofficials-promote-untested-ubhejane/.

29 Suggested by Munyaradzi Mawere, 'Possibilities for Cultivating African Indigenous Knowledge Systems (IKSs): Lessons from Selected Cases of Witchcraft in Zimbabwe', Journal of Research in Peace, Gender and Development 1 (2011): 91-100 at 98.

30 Escobar, 'Imagining a Post-Development Era?', 25.

31 Ziai, 'Development Discourse and Its Critics', 8. 
theoretical accounts of development, ${ }^{32}$ nor the programmes designed to educate the police about human rights and gender issues and to help teachers impart literacy and numeracy and, one could add, those aimed at improving the health of pregnant women and of their newborns, enhancing nutrition amongst children, providing emergency food assistance, fostering immunization, combating malaria, pneumonia and HIV/AIDS, reducing instances of child marriages, making it easier to register births with the state, and creating effective asylum systems for refugees. ${ }^{33}$ Although below I will argue that a drive to improve people's material standard of living has too often come at the cost of communal relationship, the present objection, that development utterly neglects non-economic considerations, is too crude.

\subsection{Too Little Locality?}

Often post-development theorists strongly express 'an interest in local autonomy, culture and knowledge', ${ }^{34}$ or urge us to move 'from global thinking to local thinking. ${ }^{35}$ Sometimes this is merely a concern to avoid a 'one size fits all' approach, in light of the sensible points that conditions vary from place to place and that those on the ground are most likely to be aware of the particularities of their province, country or region. By this view, certain values or norms, such as a package of human rights, might be applicable to all societies, but would need to be applied differently and accorded differential weights, given the variation in contexts.

However, other times the suggestion is the stronger, relativist idea that the local is the source of the values and norms that are appropriate

\footnotetext{
32 Amartya Sen, Development as Freedom (New York: Alfred A. Knopf, 1999); Martha Nussbaum, Women and Human Development (New York: Cambridge University Press, 2001). 33 See note 9 for the source of these programmes.

34 Escobar, 'Imagining a Post-Development Era?', 27.

35 Gustavo Esteva and Madhu Suri Prakash, 'From Global Thinking to Local Thinking', in Majid Rahnema and Victoria Bawtree (eds), The Post-Development Reader (London: Zed Books, 1997), 277-289. See also Ashish Kothari et al., 'Buen Vivir, Degrowth and Ecological Swaraj: Alternatives to Sustainable Development and the Green Economy', Development 57 (2014): 362-375 at 368-369; and Ziai, 'Post-Development Concepts?', 2.
} 
for it. One theorist remarks that 'if all previous attempts at development have failed and reformist policies do not work, where does one begin? The starting point for solutions begins with cultural relativism, a rejection and total overhaul of that closed Western window', ${ }^{36}$ while another contends that the right sort of change for people is one that 'could leave them free to change the rules and the contents of change, according to their own culturally defined ethics and aspirations'. ${ }^{37}$ Some explicitly 'bite the bullet' and reject the concept of human rights as inappropriate because of its implicit universal scope. ${ }^{38}$

However, upon supposing a basic value of communion, there is nothing morally significant in itself about locality, construed as a source of views about social progress, and, furthermore, the concept of human rights remains vital. Treating people as special in virtue of their capacity to commune means avoiding severe discordance with those who have not misused this capacity, where human rights violations are plausibly precisely that, i.e., severe forms of treating innocents as separate and inferior, subordinating them, harming them, and doing so consequent to indifference to their good or even a desire to take pleasure in their pain.

Another way to see the point is to consider that those who value communion would have little reason to prize localities that did not do so. For example, post-development theorists, or at least African ethicists, would generally not approve of the local as it exists in the West. They would instead tend to maintain that what is local there is undesirable (say, for undermining communion), which judgment entails that locality as such is not what truly motivates. For another example, suppose that a given non-Western culture would not allow girls to read or to be educated in certain subjects. ${ }^{39}$ Again, what is local would not merit

36 Erik Berg, 'Post-Development Theory in Africa', Peace Review 19 (2007): 541-554 at 544. 37 Rahnema, 'Towards Post-Development', 385.

38 E.g., Esteva and Prakash, 'From Global Thinking to Local Thinking', 282-285.

39 For a similar point, about the potential clash between infant mortality and multiculturalism, see Ray Kiely, 'The Last Refuge of the Noble Savage? A Critical Assessment of Post-Development Theory', European Journal of Development Research 11 (1999): 30-55. 
funding or other kinds of support, roughly for failing to commune with the girls.

\subsection{Too Much Progress?}

For the fifth and final objection to development sometimes made in the name of African values that I argue is weak, ${ }^{40}$ note that some reject development because it implies linearity or progress. Sometimes this objection is grounded on the idea that development means indefinite economic growth, ${ }^{41}$ an association that I argued above is not necessary; in the $21^{\text {st }}$ century relatively few development theorists believe that it should take the form of pursuing the constant expansion of the monetary value of goods and services. However, other times the criticism is not based on this merely contingent association and appears to cut to the heart of the concept of development. Consider these claims:

According to Ubuntu and Buen Vivir, there is no such a thing as underdevelopment. Rather, the problem is social disharmony ... [where the] primary aim is not to achieve progress, but rather to establish harmonious relations. ${ }^{42}$

40 A sixth prominent objection that I find weak is that development posits only one, and specifically Western, way for a society to progress. Consider, for example, the title of Serge Latouche, The Westernization of the World (Cambridge, MA: Polity, 1996), as well as talk of development theory being 'unidirectional' (Kothari et al., 'Buen Vivir, Degrowth and Ecological Swaraj', 366), or 'homogenizing' the non-West (Berg, 'Post-Development Theory in Africa', 553), or 'universalizing Western institutions' (Ziai, 'Development Discourse and Its Critics', 4). While I agree that there is prima facie reason to doubt that there is only one way for societies to progress, strong reason to doubt that the West instantiates it, and extremely strong reason to contend that it should not be forcibly imposed on others, this criticism would be much more compelling if informed by specific values that have some philosophical backing and concrete, plausible alternatives in light of them (at least the former of which I aim to provide here). For an influential critique of the lack of positive suggestions in post-development theory, see Jan Pieterse, 'After Post-development', Third World Quarterly 21 (2000): 175-191 at 184-186, 188.

41 Sindima, 'Community of Life', 542-543; Rahnema, 'Towards Post-Development', 392, 393,400 .

42 Marianne Kuusipalo, 'Harmony versus Progress: Development from the Perspective of Indigenous Worldviews', Horn of Africa Journal 7 (2014), http://afrikansarvi.fi/72artikkeli/203-harmony-versus-progress. 
The problem is not in the lack of implementation, but rather in the concept of development as linear ... In indigenous knowledge, there is nothing analogous to the concept of development, often leading to a rejection of that idea. There is no concept of a linear process of life to establish a before and after state, namely underdevelopment and development, referring to the dichotomy in which people have to go through in order to achieve welfare, as in the Western world. ${ }^{43}$

Is it true that, for indigenous African values, the concepts of progress and linearity are out of place?

I believe not. Consider that, at the individual level, it is extremely common for indigenous Africans to invoke the maxim, 'A person is a person through other persons' (or ones like it such as 'I am because we are'). Although there are descriptive senses to this phrase (to the effect that one's existence and identity necessarily depend on others), there is also a prescriptive sense, namely, that one ought to become a real person, which one can do by prizing certain relationships with others. ${ }^{44}$ Traditionally speaking, one should strive to become an ancestor, or at least as morally wise as one can become. Those who have utterly failed to exercise their capacity to commune and have acted in vicious ways are often labelled 'non-persons' or even 'animals'.

Now, given that the idea of self-realization or self-improvement, viz., moving away from being an animal (a before state) and towards becoming a real person (an after state), has in fact been salient in traditional sub-Saharan ethical thought, it is hardly a stretch to think in similar terms at a social level. If our aim as individuals should be to become good people, then a society's aim should plausibly be to create good institutions, roughly ones that enable and prompt individuals to realize themselves as communal beings. If a society is failing to honour its people's special capacity to commune, then there is a reasonable sense of 'progress' that it should be striving to achieve.

43 Kothari et al., 'Buen Vivir, Degrowth and Ecological Swaraj, 366, 367.

44 For just one exposition, in the context of a variety of sub-Saharan peoples, see Mutombo Nkulu-N'Sengha, 'Bumuntu', in Molefi Kete Asante and Ama Mazama (eds), Encyclopedia of African Religion (Los Angeles: Sage, 2009), 142-147. 


\section{Strong Criticisms of Development}

Having argued that several criticisms of development theory and practice miss their mark, from the perspective of an Afro-communal normative framework, I now argue that there are three criticisms that are on target. I am not the first to voice these criticisms, but take my contribution to be showing that communion naturally provides a unitary ground accounting for their force.

\subsection{Too Anthropocentric}

As noted above, standard development theory and practice now routinely integrate a concern for the environment. However, pollution is to be avoided only insofar as it would harm human beings, and sustainability is to be pursued only in the sense of using nature now in ways that are consistent with the flourishing of future generations of human beings. These approaches to the environment do not take into account what noninstrumental goodness or moral status exists beyond the human realm. 'Unless people cultivate a sense of bondedness to nature they cannot care about nature ... Any model of transformation that does not take into account the value of nature does not stand a chance'. ${ }^{45}$

The Afro-communal ethic above entails that progress ought to be conceived as including the fulfilment of certain direct duties towards those animals that can be objects of communion with us. Recall that, by this ethic, human beings have a full moral status insofar as they can commune and many animals have a partial moral status in that they can be communed with by us. Although our full moral status means that our urgent or most important interests should be favoured when they unavoidably conflict with those of animals, their partial moral status means that our trivial interests, and perhaps some of our moderate ones, should not be satisfied at the expense of their urgent ones in (at least) being free from anxiety and physical pain.

45 Sindima, 'Community of Life', 549; see also Kothari et al., 'Buen Vivir, Degrowth and Ecological Swaraj, 371. 
Hence, a morally sound conception of social progress would be one that seeks to give animals their due, and does not imply that they should serve merely as a means to our ends. When evaluating a society, one ought to consider, as Bhutan's Gross National Happiness index has for decades, ${ }^{46}$ how to avoid degrading non-anthropocentric values, or, in the relational terms favoured here, how to satisfy human interests while minimizing the subordination of and harm to animals capable of being party to communal relationships with us. A more stringent regulation, if not abolition, of factory farms would be a good way to start embarking on a more harmonious relationship with the most valuable parts of the natural world. As Gandhi is famous for having said, 'The greatness of a nation and its moral progress can be judged by the way its animals are treated'.

\subsection{Too Individualist}

Above I argued that development theory and practice cannot be faulted for being exclusively concerned with material, financial or economic considerations, as they have also routinely addressed health, education and human rights. What $\mathrm{I}$ do think is a fair criticism is the idea that a developmental approach to all these interests is overly individualist, by which I mean focused on improving goods internal to individuals and not giving enough weight to relational values.

To begin to appreciate this criticism, consider that one group of scholars au fait with the Senegalese context have suggested that wealth should be identified not in terms of the number of objects acquired or purchasing power, but rather

in the level of integration of people in their natural and spiritual environments, in the quality of their relationships with the society around them ... If we were to evaluate the wealth of a society ... according to its capacity to integrate and 'include' the greatest number of people; if we also

46 On which see Sabine Alkire, 'Well-being, Happiness, and Public Policy', Oxford Poverty and Human Development Initiative Research in Progress Series (2013), 41-42, http://www.alicerap.eu/resources/documents/cat_view/18-well-being-library.html. 
assessed its capacity to redistribute-one would be led to conclude that many in the West live in a state of poverty and precariousness. ${ }^{47}$

Similarly, consider the remark,

If one defined violent crime, racism, suicide, isolation, alienation, environmental destruction and the like as major indicators of a 'bad' or 'underdeveloped' society, the industrialized countries would hardly be at the top of the 'development' scale. ${ }^{48}$

Taking communion to be a basic value makes good sense of these criticisms of development. It is plausible to think of integration as a matter of people identifying with and exhibiting solidarity towards others, and to deem problems such as crime, racism, isolation, alienation and the like to be the undermining of these values and the manifestation of their opposites in the forms of division and ill-will.

More than a few thinkers who have been inspired by Africa and criticized development have pointed out that Western economic norms tend to undermine certain relational orientations prominent in the lives of indigenous sub-Saharans. Here are several examples (not intended to be complete):

- the profit motive has often conflicted with the prestige motive, viz., the intention to give without immediate expectation of net gain or even equivalent return, common amongst indigenous African peoples; ${ }^{49}$

- relatedly, there has been a disposition amongst sub-Saharans not to accumulate wealth, but rather to spend it with the expectation of sustaining and deepening bonds, on which one could rely

47 Emmanuel N'Dione et al., 'Reinventing the Present: The Chodak Experience in Senegal', in Majid Rahnema and Victoria Bawtree (eds), The Post-Development Reader (London: Zed Books, 1997), 364-376 at 369.

48 Ziai, 'Development Discourse and Its Critics', 8. See also Rahnema, 'Towards PostDevelopment', 384 .

49 N'Dione et al., 'Reinventing the Present', 371-372; and Munyaradzi Felix Murove, 'The Incarnation of Max Weber's Protestant Ethic and the Spirit of Capitalism in Post-colonial African Economic Discourse', repr. in Munyaradzi Felix Murove (ed.), African Ethics (Pietermaritzburg: University of KwaZulu-Natal Press, 2009), 221-237. 
down the road; ${ }^{50}$

- $\quad$ rather than deploy labour-saving technology, many indigenized Africans would employ their relatives and friends in an 'economy of affection'; ${ }^{51}$

- in contrast to a banking model, it would be natural for those inspired by indigenous African values to pool their resources and then loan them out either without seeking interest or on a profit-sharing basis ${ }^{52}$

- instead of those living on a plot of land being solely responsible for gathering up the produce from it, all those who had harvesting to do in many traditional sub-Saharan villages would collectively move from field to field to help one another, ${ }^{53}$

- $\quad$ rather than export goods to the global market, African traders would often prefer to make goods that would benefit their compatriots; there is something prima facie wrong with a situation 'where in a country with coffee crops it is impossible to drink local coffee (there is only imported instant one)' $;{ }^{54}$

- $\quad$ instead of conceiving of poverty as bad simply because one's own needs go unmet, one should allow for the idea that 'the problem

50 Kofi Busia, The Challenge of Africa (New York: Frederick A. Praeger, Inc., 1962), 131; N'Dione et al., 'Reinventing the Present', 370; Hassan Zaoual, 'The Economy and Symbolic Sites of Africa' in Majid Rahnema and Victoria Bawtree (eds), The Post-Development Reader (London: Zed Books, 1997), 30-39 at 34-36; and Murove, 'The Incarnation of Max Weber's Protestant Ethic and the Spirit of Capitalism in Post-colonial African Economic Discourse', 231-232.

51 Zein-Elabdin, 'Postcoloniality and Development', 224-225.

52 See discussions of South African stokvels in Dirk Louw, 'Ubuntu and the Challenges of Multiculturalism in Post-apartheid South Africa', Quest 15 (2001): 15-35 at 24-25, and of Senegalese tontine in Berg, 'Post-Development Theory in Africa', 552.

53 See, e.g., discussion of the southern African practice of letsema in Moeketsi Letseka, 'African Philosophy and Educational Discourse', in Philip Higgs et al. (eds), African Voices in Education (Lansdowne: Juta, 2000), 179-193 at 183-184, 189-190.

54 Lubieniecka, 'Does Post-development Theory Find Alternatives to Westernization of International Relations?', 11-12. 
with being poor is that I don't have anything to give to others, ${ }^{55}$ which entails making allowance for some transferable goods, or at least those that can be shared by more than one agent at a time, and not merely goods that are non-transferable and indivisible;

- $\quad$ rather than focus solely or mainly on money or commodities as what to ensure are distributed, goods or services to prioritize in light of African values would include couples counselling, women's shelters, parenting classes, quality day care, rehabilitation programmes, neighbourhood parks and festivals, densification in spacious neighbourhoods, job training, nonexploitive labour relations and grassroots organizations; ${ }^{56}$

- $\quad$ rather than permit great inequalities of wealth, even if they were to the marginal financial benefit of the worst-off, many in the African tradition would find reason to reduce them so as to avoid envy and to foster a greater sense of togetherness. ${ }^{57}$

The literature on African values features mainly these kinds of economic examples where development would appear to come at the cost of relationship, but it is worth noting parallel cases in the spheres of healthcare, education and human rights. Extending the criticism in these ways is important in order to clarify that an essential problem with development is not so much materialism, but rather the deeper and broader problem of individualism. So, for example, consider the view that a family has a right to be informed about the sickness of one of its members, or at least that a person has a duty to inform them about his

55 A remark from an elderly South African woman made at an imbizo (discussion between leaders and their community) on the topic of ubuntu and poverty, quoted by Thaddeus Metz, 'An African Theory of Dignity and a Relational Conception of Poverty', in John de Gruchy (ed.), The Humanist Imperative in South Africa (Stellenbosch: African Sun Media, 2011), 233-241 at 238.

56 Argued in Metz, 'An African Theory of Dignity and a Relational Conception of Poverty'. 57 Magesa, African Religion, 278; and Henry Odera Oruka, Practical Philosophy (Nairobi: East African Educational Publishers, 1997), 120. 
sickness and hence how his ability to help them might be impaired. ${ }^{58}$ Such an approach to confidentiality conflicts with the dominant approach in the West, which treats information about health as the patient's private information.

Or think about the idea that one proper aim of education is to enculturate, i.e., to transmit and enrich a local way of life that has been central to a people's self-conception for a long time. ${ }^{59}$ Such a concern to support an instance of communion contrasts with the view of education salient in the West, that its aim should be merely or mainly to enable students to rationally choose in cosmopolitan fashion from amongst a variety of global possibilities.

Finally, with respect to human rights, notice that several prominent African political philosophers have argued that democratic political power would be best allocated on a consensual basis, so that, for example, a statute should be considered valid only if all Parliamentarians agreed to its adoption. ${ }^{60}$ Such diverges from the ubiquitious system in the West, where political parties are allowed to push through statutes based on majority rule, which is much more competitive and exclusionary.

These examples of prima facie plausible forms of relationality in the realms of healthcare, education and human rights could be multiplied. I submit that the value of communion as sketched above does a powerful job of explaining how typical development strategies often objectionably come at the expense of relational goods. Note, however, that I am not suggesting that there is conclusive reason to deem all these specific relational examples to be appropriate; they need to be weighed against

58 E.g., Peter Kasenene, 'African Ethical Theory and the Four Principles', in Robert Veatch (ed.), Cross-Cultural Perspectives in Medical Ethics (Sudbury, MA: Jones \& Bartlett, 2000), 347357 at 349-356.

59 E.g., Ivy Goduka, 'African/Indigenous Philosophies: Legitimizing Spiritually Centered Wisdoms within the Academy', in Philip Higgs et al. (eds), African Voices in Education (Lansdowne: Juta, 2000), 63-83.

60 For just one influential example, see Kwasi Wiredu, 'Democracy by Consensus', Philosophical Papers 30 (2001): 227-244. 
more competitive or otherwise atomistic mechanisms that might be expected to improve people's quality of life substantially, thereby realizing solidarity of a sort (between institutions and the people they ought to serve), even if at some cost to interpersonal identity and face-toface mutual aid.

\subsection{Too Technocratic}

For the third criticism of development that I believe is incisive, consider that even those who question post-development theory tend to grant that one of its purportedly negative characterizations of development theory and practice is correct: 'Development thinking is steeped in social engineering and the ambition to shape economies and societies, which makes it an interventionist and managerialist discipline'. ${ }^{61}$ The literature abounds with bitter criticism of development 'experts' and 'managers' who advise and oversee programmes, occluding more democratic approaches, say, where intended beneficiaries would be involved in the construction of the programmes.

As has been recently noted, "the importance of "participation" has been taken on board, at least nominally, by the major international development agencies'. ${ }^{62}$ The question that remains is whether the logic of development theory can adequately explain why participation is morally important.

The central developmental rationale for participation is one of efficiency: without input from the poor, a programme intended to benefit them would be less likely to work. Generally speaking, people best know their own interests and how to realize them, a point that John Stuart Mill is famous for having invoked in his political philosophy. And, so, a development theorist might reasonably contend that consultation

61 Pieterse, 'After Post-Development', 182; see also Ziai, 'Development Discourse and Its Critics', 8-9; and James Ferguson, The Anti-Politics Machine: 'Development,' Depoliticization and Bureaucratic Power in Lesotho (Cambridge: Cambridge University Press, 1990).

62 Stephen Devereux and J. Allister McGregor, ‘Transforming Social Protection', European Journal of Development Research 26 (2014): 296-310 at 299. 
with intended beneficiaries is normally vital in order to be able to ensure that a programme will indeed help them.

However, there are two problems with this rationale for participation. First, it is not always the case that consultation with the poor would assist in doing what is most likely to help them. Sometimes policy-makers and activists can be in a position to know on their own what would be good for others. After all, imagine the poor's lack of education were to get in the way and cause problems when trying to craft an effective programme; in such a case, if a top-down approach would likely produce marginally better outcomes for the poor in the long run, the logic of development theory would justify it.

Second, a requirement to consult with the poor does not seem reducible to mere considerations of efficiency. There is intuitively some moral reason to include the poor that is independent of the epistemic consequences of doing so. There is something about a participative process that matters in itself or for its own sake when it comes to justice; there would be reason to consult with intended beneficiaries even were it the case that their lack of education would make it more difficult to help them.

Now, considerations of communion naturally give substantial moral weight to the procedure by which programmes are undertaken. The way that goods or services are distributed must be done in a way that esteems relationships of identity and solidarity. It is the former element that does real work in the present context; for identifying with others is roughly a matter of enjoying a sense of togetherness and engaging in joint projects. These factors have an intrinsic significance for morally sound relationships distinct from caring (doing what is likely to improve people's quality of life), and they make good sense of why there is strong moral reason for programmes to be participatory, beyond considerations of efficiency. Participation could range from consultation to cooperation or, as one scholar has forcefully suggested, to the provision of resources 
to enable the poor to undertake their own, grassroots projects. ${ }^{63}$

\section{Conclusion: Towards a Relational Concept of Progress}

I have argued that, even upon detaching talk of 'development' from the aim of indefinite economic growth, there are three key respects in which its characteristic theory and practice remain morally questionable. Specifically, they are still overly anthropocentric, individualist and technocratic. The African value of communion qua identity and solidarity provides a normative theoretical ground for making these three criticisms and for prescribing a different form of progress, one that includes relating to certain animals as ends, that does not invariably trade-off relational goods for non-relational ones, and that includes a participatory dimension at its core.

One major question at this point is how to speak about the direction in which a society ought to move. Some would characterize the relational values sketched in this article as informing an 'African development'. ${ }^{64}$ However, if I am correct that for more than 60 years the word 'development' has signified an anthropocentric, individualist and technocratic approach, then such a phrase would be a contradiction in terms (supposing that 'African' signified communion). Although there would be something appealing about composing an article that invokes the value of communion and sports the title 'How the West Is Underdeveloped', I am more inclined to let talk of 'development' go and instead to work with a different vocabulary.

Contra many in the post-development movement, I do not also eschew talk of 'progress' or the concept of linearity. Central to the

63 Sally Matthews, 'What, Then, Should We Do? Insights and Experiences of a Senegalese NGO', in Aram Ziai (ed.), Exploring Post-Development (New York: Routledge, 2007), 131144.

64 In addition to Prah, 'Culture', see Martin Ajei, Africa's Development: The Imperative of Indigenous Knowledge and Values (Saarbrücken: Lambert Academic Publishing, 2011); and Lansana Keita, 'Philosophy and Development: On the Problematic African Development', in Lansana Keita (ed.), Philosophy and African Development Theory and Practice (Dakar: CODESRIA, 2011), 115-137. 
African ethical tradition has been the view that people ought over time to become real persons, often construed in terms of their capacity to relate to others in certain, social ways. Since it makes sub-Saharan sense to say that some, immoral individuals live akin to animals and that they ought to mature, by working to manifest their genuinely humancommunal features, undesirable societies seem aptly construed as those in which it is difficult for people to do so and in which key institutions instead flout the value of communion. From this perspective, a bad society is roughly one tends to produce bad lives, ones that are inhuman for their relationships too often being anti-social or discordant.

In sum, instead of 'growth' or 'development', perhaps we should try talk of 'humanization'. And since the West has not done a particularly good job of humanizing its institutions and relationships more generally, and since communion has not been a salient foundational value in its moral-political philosophy, the default respect in which the West ought to seek to aid Africa is by providing resources with which it could take the lead in enabling its people to become real people by communing with other people (and animals). ${ }^{65}$

University of Johannesburg

tmetz@uj.ac.za

65 For written comments on a prior draft of this article, I thank Sally Matthews and an anonymous referee for Philosophical Papers. For oral comments, I am grateful to participants at a Conference on Morality, Politics, and the Idea of Progress that was held at the University of Ghana-Legon and sponsored by The Leverhulme Trust as part of its International Networks project on Domesticating Global Justice: Normative Global Theorising in Modern African Contexts. 